\title{
Effect of Different Precooling and Storage Temperatures on Shelf Life of Mango cv. Alphonso
}

\author{
N.M. Kanade*, C.D. Pawar, V.S. Ghule, R.C. Gajbhiye and B.R. Salvi \\ Department of Horticulture, Dr. Balasaheb Sawant Konkankrishividyapeeth, \\ Dapoli. MS- 415712, India \\ *Corresponding author
}

\section{A B S T R A C T}

An experiment was conducted to study the effect of different precooling and storage temperatures on shelf life of mango cv. Alphonso. The experiment was carried out during

\begin{tabular}{|c|c|}
\hline Keywords & $\begin{array}{l}\text { the season May } 2016 \text { at R.F.R.S., Vengurle, Dr. Balasaheb Sawant Konkan krishi } \\
\text { vidyapeeth, Dapoli with five precooling temperatures }\left(\mathrm{P}_{1}-\text { Control, } \mathrm{P}_{2}-21 \pm 2^{\circ} \mathrm{C}, \mathrm{P}_{3}-18\right. \\
\left. \pm 2^{\circ} \mathrm{C}, \mathrm{P}_{4}-15 \pm 2^{\circ} \mathrm{C} \text { and } \mathrm{P}_{5}-12 \pm 2^{\circ} \mathrm{C} \text {. }\right) \text { and four storage temperatures }\left(\mathrm{S}_{1}-\text { Ambient }\right. \\
\left.\text { temperature }\left(27-30{ }^{\circ} \mathrm{C}\right), \mathrm{S}_{2}-18 \pm 2{ }^{\circ} \mathrm{C}, \mathrm{S}_{3}-15 \pm 2^{\circ} \mathrm{C} \text { and } \mathrm{S}_{4}-12 \pm 2^{\circ} \mathrm{C} \text {. }\right) \text {. After precooling } \\
\text { fruits were store for } 21 \text { days at different storage temperatures and after } 21 \text { days again }\end{array}$ \\
\hline Arti & $\begin{array}{l}\text { brought to above precooling temperature by air cooling. Then the cooled fruits are kept for } \\
\text { ripening for seven days at room temperature. The experiment was laid out in FCRD with }\end{array}$ \\
\hline $\begin{array}{l}\text { Accepted: } \\
10 \text { September } 2017 \\
\text { Available Online: } \\
10 \text { November } 2017\end{array}$ & $\begin{array}{l}\text { wo replications. The interaction } \mathrm{P}_{5} \mathrm{~S}_{4} \text { (Precooling at } 12 \pm 2^{\circ} \mathrm{C} \text { and storage at } 15 \pm 2{ }^{\circ} \mathrm{C} \text {.), } \\
\text { howed the minimum physiological loss in weight (PLW) }(9.11 \%) \text { followed by } \mathrm{P}_{5} \mathrm{~S}_{3} \\
11.48 \% \text { ), the interaction } \mathrm{P}_{5} \mathrm{~S}_{3} \text { recorded minimum shrivelling }(0.00 \%) \text { and the interaction } \\
{ }_{5} \mathrm{~S}_{4} \text { recorded minimum spoilage }(4.00 \%) \text { at } 28 \text { days of storage. The interaction } \mathrm{P}_{5} \mathrm{~S}_{3} \text { and }\end{array}$ \\
\hline & $\begin{array}{l}\mathrm{S}_{4} \text { observed the maximum shelf life ( } 28 \text { days } \\
\text { nificantly superior over others. }\end{array}$ \\
\hline
\end{tabular}

\section{Introduction}

Mango (Mangifera indica L.) is the oldest and 'National Fruit of India' and rightly known as 'King of Fruits' owing to its nutritional richness, unique taste, pleasant aroma and religious and medicinal importance. Mango is believed to be originated to South East Asia, Indo-Burma region, in foot hills of the Himalayas (Mukherjee, 1951). India is the largest producer of mango in the world and ranks first in area and production. The total production of mango in India is 18.832 million MT from about 2.218 million ha area with the productivity of $8.49 \mathrm{MT} / \mathrm{ha}$ (Anon., 2015 a). In Maharashtra, mango is occupying an area of 0.156 million ha with annual production of 0.876 million $\mathrm{MT}$ and productivity of 5.60 MT/ha (Anon., 2015b). Post-harvest handling is the problem of mango as due to climacteric nature of the fruit. So, post-harvest handling can play a major role to reduce the losses. The postharvest losses in mango are about 25 to 30 per cent post-harvest losses. This is mainly due to the non-availability of commercial low temperature store houses, lack of cool chain during transport and storage (Krishnamurthy and Rao, 2001). Temperature is the most important environmental factor that will 
influence the deterioration of harvested fruits, hence its management during various postharvest operations like pre-cooling, handling and storage plays a major role for extending the shelf-life. Padhye (1997) observed that the mango fruit cv. Alphonso stored at cold storage $\left(12.7-15.0^{\circ} \mathrm{C}\right.$ and $85-89$ $\% \mathrm{RH}$ ) condition had maximum shelf life (2426 days). Alphonso is premium export cultivar and the export by air is very costly. Hence, if shelf life of fruits increased up to about 30 days, it can be exported through sea route. This will reduce the freight cost and will boost the export of fresh fruits. The research work on prolonging the self-life is of utmost importance for reducing the freight charges of air and fetch higher revenue for mango growers. Cold storage facility help in regulating market supply and stabilize the rates. Similarly, to extend shelf life, precooling after harvest is necessary. However, harvested mango fruits, are kept in cold storage with or without precooling. After storage they are directly brought to ambient temperature for ripening. This affects the quality of fruits and cause losses. In order to reduce these losses, it is necessary to standardize precooling and storage methods at different temperatures. Most of the work was done on storage and precooling separately but combine effect of both precooling and storage was not studied. In view of this, the present study was envisaged to study the effect of different precooling and storage temperatures on shelf life of mango cv. Alphonso.

\section{Materials and Methods}

Physiologically mature, hard green fruits at optimum maturity of mango Cv. Alphonso were harvested with the help of Nutan Zela with keeping 2.5 to $3.5 \mathrm{~cm}$ stalk during morning hours from the Regional Fruit Research Station, Vengurle Dist. Sindhudurg (Dr. Balasaheb Sawant Konkan Krishi Vidyapeeth, Dapoli) during May 2016. After harvesting, the fruits were treated with $0.1 \%$ carbendazine and kept under shade for 1-2 hours in order to dry them. The experiment was laid out in Factorial Completely Randomized Design (FCRD) with two replications. Initial observation was recorded and fruits were kept in forced air cooling chamber for the pre-cooling at $\mathrm{P}_{1}-$ Control, $\mathrm{P}_{2}-21 \pm 2{ }^{0} \mathrm{C}, \mathrm{P}_{3}-18 \pm 2{ }^{\circ} \mathrm{C}, \mathrm{P}_{4}-15 \pm 2{ }^{\circ} \mathrm{C}$ and $\mathrm{P}_{5}-12 \pm 2{ }^{\circ} \mathrm{C}$. The precool temperature was checked by using thermometer which was inserted in the pulp of the fruit and the constant temperature maintained. Precooled fruits were stored for 21 days at different storage temperature like $\mathrm{S}_{1}$-Ambient temperature $\left(27-30{ }^{\circ} \mathrm{C}\right), \mathrm{S}_{2}-18 \pm 2{ }^{\circ} \mathrm{C}, \mathrm{S}_{3}-$ $15 \pm 2{ }^{0} \mathrm{C}$ and $\mathrm{S}_{4}-12 \pm 2{ }^{0} \mathrm{C}$. After 21 days storage, fruits were again brought to above precooling temperature by forced air cooling and kept for ripening for 7 days at room temperature.

\section{Results and Discussion}

\section{Physiological loss in weight (PLW) (\%)}

It is observed from Table 1 and Figure 1 the PLW of mango fruits increased continuously throughout the storage period, irrespective of precooling and storage temperatures. At $7^{\text {th }}$ day the lowest $(0.84 \%)$ PLW was observed in storage temperature $15 \pm 2^{\circ} \mathrm{C}\left(\mathrm{S}_{3}\right)$ and was superior over rest of the storage temperatures. The storage temperature $15 \pm 2^{\circ} \mathrm{C} \quad(\mathrm{S} 3)$ recorded significantly the lowest PLW (5.19 $\%)$ and minimum PLW were recorded in interaction $\mathrm{P}_{5} \mathrm{~S}_{3}(3.22 \%)$ which was at par with $\mathrm{P}_{1} \mathrm{~S}_{3}(4.15 \%)$, and $\mathrm{P}_{2} \mathrm{~S}_{3}(4.02 \%)$ on $21^{\text {st }}$ day of storage. At $28^{\text {th }}$ day of storage in interactions the minimum increase in PLW was observed in $\mathrm{P}_{5} \mathrm{~S}_{4}(9.11 \%)$ followed by $\mathrm{P}_{5} \mathrm{~S}_{3}(11.48 \%)$. In case of storage conditions, fruits stored in cold storage showed minimum increase in PLW as compared to ambient temperature. The continuous increase in PLW in both the storage conditions and precooling could be due to loss of moisture from the skin of fruits through respiration and transpiration. 
Table.1 Effect of precooling and storage temperatures on PLW (\%) (physiological loss in weight) of mango fruits during storage

\begin{tabular}{|c|c|c|c|c|c|c|c|c|c|c|c|c|c|c|c|c|c|c|}
\hline \multirow{2}{*}{$\begin{array}{l}\text { Treat- } \\
\text { ment }\end{array}$} & \multicolumn{6}{|c|}{0 Days } & \multicolumn{6}{|c|}{7 Days } & \multicolumn{6}{|c|}{14 Days } \\
\hline & $\mathbf{P 1}$ & $\mathbf{P 2}$ & P3 & $\mathbf{P 4}$ & P5 & Mean & $\mathbf{P 1}$ & $\mathbf{P 2}$ & P3 & $\mathbf{P 4}$ & P5 & Mean & $\mathbf{P 1}$ & $\mathbf{P 2}$ & P3 & P4 & P5 & Mean \\
\hline S1 & 0 & 0 & 0 & 0 & 0 & 0 & 7.62 & 8.53 & 6.44 & 8.29 & 8.78 & 7.93 & 15.82 & 17.26 & 16.08 & 17.24 & 20.23 & 17.33 \\
\hline S2 & 0 & 0 & 0 & 0 & 0 & 0 & 4.03 & 1.62 & 0.90 & 1.53 & 1.28 & 1.87 & 3.11 & 3.63 & 1.70 & 4.72 & 4.27 & 3.49 \\
\hline S3 & 0 & 0 & 0 & 0 & 0 & 0 & 0.37 & 0.68 & 1.35 & 1.07 & 0.75 & 0.84 & 2.40 & 2.25 & 3.35 & 3.94 & 0.98 & 2.58 \\
\hline S4 & 0 & 0 & 0 & 0 & 0 & 0 & 1.30 & 1.40 & 1.40 & 1.39 & 0.80 & 1.26 & 3.73 & 4.70 & 3.25 & 3.80 & 4.25 & 3.94 \\
\hline \multirow[t]{2}{*}{ Mean } & 0 & 0 & 0 & 0 & 0 & 0 & 3.33 & 3.06 & 2.52 & 3.07 & 2.90 & 2.98 & 6.26 & 6.96 & 6.10 & 7.42 & 7.43 & 6.83 \\
\hline & \multicolumn{3}{|c|}{ S.Em+ } & \multicolumn{3}{|c|}{ C.D. @1\% } & \multicolumn{3}{|c|}{ S.Em+ } & \multicolumn{3}{|c|}{ C.D.@1\% } & \multicolumn{3}{|c|}{ S.Em+ } & \multicolumn{3}{|c|}{ C.D.@1\% } \\
\hline $\mathbf{S}$ & \multicolumn{3}{|c|}{-} & \multicolumn{3}{|c|}{-} & \multicolumn{3}{|c|}{0.05} & \multicolumn{3}{|c|}{0.19} & \multicolumn{3}{|c|}{0.23} & \multicolumn{3}{|c|}{0.91} \\
\hline $\mathbf{P}$ & \multicolumn{3}{|c|}{-} & \multicolumn{3}{|c|}{-} & \multicolumn{3}{|c|}{0.05} & \multicolumn{3}{|c|}{0.21} & \multicolumn{3}{|c|}{0.25} & \multicolumn{3}{|c|}{1.02} \\
\hline SxP & \multicolumn{3}{|c|}{-} & \multicolumn{3}{|c|}{-} & \multicolumn{3}{|c|}{0.11} & \multicolumn{3}{|c|}{0.43} & \multicolumn{3}{|c|}{0.51} & \multicolumn{3}{|c|}{2.04} \\
\hline Treat- & & & $21 \mathrm{I}$ & ays & & & & & 28 I & ays & & & & & & & & \\
\hline ment & P1 & $\mathbf{P 2}$ & P3 & P4 & P5 & Mean & P1 & $\mathbf{P 2}$ & P3 & P4 & P5 & Mean & & & & & & \\
\hline S1 & 23.77 & 24.22 & 22.69 & 27.12 & 25.72 & 24.70 & - & - & - & - & - & - & & & & & & \\
\hline S2 & 6.77 & 5.60 & 6.08 & 5.73 & 6.09 & 6.05 & 16.46 & 13.43 & 18.97 & 15.64 & 14.27 & 15.75 & & & & & & \\
\hline S3 & 4.15 & 4.02 & 8.56 & 5.98 & 3.22 & 5.19 & 13.88 & 13.73 & 16.16 & 18.95 & 11.48 & 14.84 & & & & & & \\
\hline S4 & 7.77 & 6.67 & 6.52 & 6.59 & 6.40 & 6.79 & 15.08 & 15.44 & 15.57 & 17.51 & 9.11 & 14.54 & & & & & & \\
\hline Mean & 10.62 & 10.13 & 10.96 & 11.36 & 10.36 & 10.68 & - & - & - & - & - & - & & & & & & \\
\hline & & S.Em+ & & & D. @1 & & & S.Em+ & & & D. @1 & & & & & & & \\
\hline $\mathbf{S}$ & & 0.14 & & & 0.57 & & & - & & & - & & & & & & & \\
\hline $\mathbf{P}$ & & 0.16 & & & 0.64 & & & - & & & - & & & & & & & \\
\hline SxP & & 0.32 & & & 1.28 & & & - & & & - & & & & & & & \\
\hline
\end{tabular}


Table.2 Effect of precooling and storage temperature on shrivelling (\%) of mango fruits during storage

\begin{tabular}{|c|c|c|c|c|c|c|c|c|c|c|c|c|c|c|c|c|c|c|}
\hline \multirow{2}{*}{$\begin{array}{l}\text { Treat- } \\
\text { ment }\end{array}$} & \multicolumn{6}{|c|}{ O Days } & \multicolumn{6}{|c|}{7 Days } & \multicolumn{6}{|c|}{14 Days } \\
\hline & P1 & $\mathbf{P 2}$ & P3 & P4 & P5 & Mean & P1 & $\mathbf{P 2}$ & P3 & P4 & P5 & Mean & P1 & $\mathbf{P 2}$ & P3 & P4 & P5 & Mean \\
\hline S1 & 0 & 0 & 0 & 0 & 0 & $\mathbf{0}$ & 0 & 0 & 0 & 0 & 0 & $\mathbf{0}$ & 14 & 10 & 10 & 10 & 8 & 10.4 \\
\hline S2 & 0 & 0 & 0 & 0 & 0 & 0 & 0 & 0 & 0 & 0 & 0 & $\mathbf{0}$ & 2 & 0 & 0 & 0 & 0 & 0.4 \\
\hline S3 & 0 & 0 & 0 & 0 & 0 & $\mathbf{0}$ & 0 & 0 & 0 & 0 & 0 & $\mathbf{0}$ & 0 & 0 & 0 & 0 & 0 & $\mathbf{0}$ \\
\hline S4 & 0 & 0 & 0 & 0 & 0 & $\mathbf{0}$ & 0 & 0 & 0 & 0 & 0 & $\mathbf{0}$ & 0 & 0 & 0 & 0 & 0 & 0 \\
\hline \multirow[t]{2}{*}{ Mean } & $\mathbf{0}$ & 0 & $\mathbf{0}$ & 0 & $\mathbf{0}$ & $\mathbf{0}$ & 0 & $\mathbf{0}$ & 0 & 0 & 0 & 0 & 4 & 2.5 & 2.5 & 2.5 & 2 & 2.7 \\
\hline & \multicolumn{3}{|c|}{ S.Em+ } & \multicolumn{3}{|c|}{ C.D. @1\% } & \multicolumn{3}{|c|}{ S.Em+ } & \multicolumn{3}{|c|}{ C.D.@1\% } & \multicolumn{3}{|c|}{ S.Em+ } & \multicolumn{3}{|c|}{ C.D.@1\% } \\
\hline $\mathbf{S}$ & \multicolumn{3}{|c|}{ - } & \multicolumn{3}{|c|}{-} & \multicolumn{3}{|c|}{-} & \multicolumn{3}{|c|}{-} & \multicolumn{3}{|c|}{0.447} & \multicolumn{3}{|c|}{1.8} \\
\hline $\mathbf{P}$ & \multicolumn{3}{|c|}{-} & \multicolumn{3}{|c|}{-} & \multicolumn{3}{|c|}{-} & \multicolumn{3}{|c|}{-} & \multicolumn{3}{|c|}{0.5} & \multicolumn{3}{|c|}{ NS } \\
\hline SxP & & - & & \multicolumn{3}{|c|}{-} & \multicolumn{3}{|c|}{-} & \multicolumn{3}{|c|}{-} & \multicolumn{3}{|c|}{1} & \multicolumn{3}{|c|}{ NS } \\
\hline \multirow{2}{*}{$\begin{array}{l}\text { Treat- } \\
\text { ment }\end{array}$} & & & & $21 \mathrm{D}$ & & & & & & $8 \mathrm{Da}$ & & & & & & & & \\
\hline & P1 & $\mathbf{P 2}$ & P3 & P4 & P5 & Mean & P1 & $\mathbf{P 2}$ & P3 & P4 & P5 & Mean & & & & & & \\
\hline S1 & 46 & 64 & 62 & 70 & 48 & 58 & - & - & - & - & - & - & & & & & & \\
\hline S2 & 6 & 4 & 2 & 4 & 2 & 3.6 & 4 & 6 & 8 & 2 & 0 & 4 & & & & & & \\
\hline S3 & 2 & 0 & 0 & 0 & 0 & 0.4 & 6 & 2 & 4 & 0 & 0 & 2.4 & & & & & & \\
\hline S4 & 2 & 0 & 0 & 0 & 0 & 0.4 & 4 & 2 & 2 & 2 & 2 & 2.4 & & & & & & \\
\hline Mean & 14 & 17 & 16 & 18.5 & 12.5 & 15.6 & - & - & - & - & - & - & & & & & & \\
\hline & & S.Em & & & C.D. @ & & & 5.Em & & & C.D. & $01 \%$ & & & & & & \\
\hline $\mathbf{S}$ & & 0.80 & & & 3.22 & & & - & & & & & & & & & & \\
\hline $\mathbf{P}$ & & 0.89 & & & 3.60 & & & - & & & & & & & & & & \\
\hline SxP & & 1.79 & & & 7.20 & & & - & & & & & & & & & & \\
\hline
\end{tabular}


Table.3 Effect of precooling and storage temperatures on spoilage (\%) of mango fruits during storage

\begin{tabular}{|c|c|c|c|c|c|c|c|c|c|c|c|c|c|c|c|c|c|c|}
\hline \multirow{2}{*}{$\begin{array}{l}\text { Treat- } \\
\text { ment }\end{array}$} & \multicolumn{6}{|c|}{0 Days } & \multicolumn{6}{|c|}{7 Days } & \multicolumn{6}{|c|}{14 Days } \\
\hline & P1 & $\mathbf{P 2}$ & P3 & $\mathbf{P 4}$ & P5 & Mean & $\mathbf{P 1}$ & $\mathbf{P 2}$ & P3 & $\mathbf{P 4}$ & P5 & Mean & $\mathbf{P 1}$ & $\mathbf{P 2}$ & $\mathbf{P 3}$ & P4 & P5 & Mean \\
\hline S1 & 0 & 0 & 0 & 0 & 0 & $\mathbf{0}$ & 0 & 0 & 0 & 0 & 0 & $\mathbf{0}$ & 10 & 6 & 10 & 4 & 2 & 6.4 \\
\hline $\mathbf{S 2}$ & 0 & 0 & 0 & 0 & 0 & $\mathbf{0}$ & 0 & 0 & 0 & 0 & 0 & $\mathbf{0}$ & 2 & 0 & 0 & 0 & 0 & 0.4 \\
\hline S3 & 0 & 0 & 0 & 0 & 0 & $\mathbf{0}$ & 0 & 0 & 0 & 0 & 0 & $\mathbf{0}$ & 0 & 0 & 0 & 0 & 0 & $\mathbf{0}$ \\
\hline S4 & 0 & 0 & 0 & 0 & 0 & $\mathbf{0}$ & 0 & 0 & 0 & 0 & 0 & $\mathbf{0}$ & 0 & 0 & 0 & 0 & 0 & $\mathbf{0}$ \\
\hline \multirow[t]{2}{*}{ Mean } & $\mathbf{0}$ & $\mathbf{0}$ & $\mathbf{0}$ & $\mathbf{0}$ & $\mathbf{0}$ & $\mathbf{0}$ & $\mathbf{0}$ & 0 & $\mathbf{0}$ & $\mathbf{0}$ & $\mathbf{0}$ & $\mathbf{0}$ & 3 & 1.5 & 2.5 & 1 & 0.5 & 1.7 \\
\hline & \multicolumn{3}{|c|}{ S.Em+ } & \multicolumn{3}{|c|}{ C.D.@1\% } & \multicolumn{3}{|c|}{ S.Em+ } & \multicolumn{3}{|c|}{ C.D. @ $1 \%$} & \multicolumn{3}{|c|}{ S.Em+ } & \multicolumn{3}{|c|}{ C.D. @1\% } \\
\hline $\mathbf{S}$ & \multicolumn{3}{|c|}{-} & \multicolumn{3}{|c|}{-} & \multicolumn{3}{|c|}{-} & \multicolumn{3}{|c|}{-} & \multicolumn{3}{|c|}{0.447} & \multicolumn{3}{|c|}{1.8} \\
\hline $\mathbf{P}$ & \multicolumn{3}{|c|}{-} & \multicolumn{3}{|c|}{ - } & \multicolumn{3}{|c|}{-} & \multicolumn{3}{|c|}{-} & \multicolumn{3}{|c|}{0.5} & \multicolumn{3}{|c|}{ NS } \\
\hline SxP & \multicolumn{3}{|c|}{-} & \multicolumn{3}{|c|}{-} & \multicolumn{3}{|c|}{-} & \multicolumn{3}{|c|}{ - } & \multicolumn{3}{|c|}{1} & \multicolumn{3}{|c|}{ NS } \\
\hline Treat- & & & & Da & & & & & & $8 \mathrm{Da}$ & & & & & & & & \\
\hline ment & P1 & $\mathbf{P 2}$ & P3 & P4 & P5 & Mean & P1 & $\mathbf{P 2}$ & P3 & P4 & P5 & Mean & & & & & & \\
\hline S1 & 14 & 18 & 10 & 8 & 6 & 11.2 & - & - & - & - & - & - & & & & & & \\
\hline S2 & 10 & 10 & 6 & 4 & 2 & 6.4 & 16 & 14 & 12 & 10 & 8 & 12 & & & & & & \\
\hline S3 & 2 & 0 & 0 & 0 & 0 & 0.4 & 10 & 8 & 10 & 6 & 6 & 8 & & & & & & \\
\hline S4 & 0 & 0 & 0 & 0 & 0 & 0 & 8 & 12 & 10 & 6 & 4 & 8 & & & & & & \\
\hline Mean & 6.5 & 7 & 4 & 3 & 2 & 4.5 & - & - & - & - & - & - & & & & & & \\
\hline & & Em+ & & & C. D. & $01 \%$ & & S.Em- & & & C.D. & $1 \%$ & & & & & & \\
\hline $\mathbf{S}$ & & 0.60 & & & & & & - & & & & & & & & & & \\
\hline $\mathbf{P}$ & & 0.67 & & & & & & - & & & & & & & & & & \\
\hline SxP & & 1.34 & & & & & & - & & & & & & & & & & \\
\hline
\end{tabular}


Table.4 Effect of precooling and storage temperatures on shelf life (Days) of mango fruits during storage

\begin{tabular}{|l|l|}
\hline Treatments & Shelf Life (Days) \\
\hline $\mathbf{P}_{\mathbf{1}} \mathbf{S}_{\mathbf{1}}$ & Between 7 to 14 \\
\hline $\mathbf{P}_{\mathbf{2}} \mathbf{S}_{\mathbf{1}}$ & Between 7 to 14 \\
\hline $\mathbf{P}_{\mathbf{3}} \mathbf{S}_{\mathbf{1}}$ & Between 7 to 14 \\
\hline $\mathbf{P}_{\mathbf{4}} \mathbf{S}_{\mathbf{1}}$ & Between 7 to 14 \\
\hline $\mathbf{P}_{\mathbf{5}} \mathbf{S}_{\mathbf{1}}$ & Between 7 to 14 \\
\hline $\mathbf{P}_{\mathbf{1}} \mathbf{S}_{\mathbf{2}}$ & Between 21 to 28 \\
\hline $\mathbf{P}_{\mathbf{2}} \mathbf{S}_{\mathbf{2}}$ & Between 21 to 28 \\
\hline $\mathbf{P}_{\mathbf{3}} \mathbf{S}_{\mathbf{2}}$ & Between 21 to 28 \\
\hline $\mathbf{P}_{\mathbf{4}} \mathbf{S}_{\mathbf{2}}$ & Between 21 to 28 \\
\hline $\mathbf{P}_{\mathbf{5}} \mathbf{S}_{\mathbf{2}}$ & Between 21 to 28 \\
\hline $\mathbf{P}_{\mathbf{1}} \mathbf{S}_{\mathbf{3}}$ & Between 21 to 28 \\
\hline $\mathbf{P}_{\mathbf{2}} \mathbf{S}_{\mathbf{3}}$ & Between 21 to 28 \\
\hline $\mathbf{P}_{\mathbf{3}} \mathbf{S}_{\mathbf{3}}$ & Between 21 to 28 \\
\hline $\mathbf{P}_{\mathbf{4}} \mathbf{S}_{\mathbf{3}}$ & Between 21 to 28 \\
\hline $\mathbf{P}_{\mathbf{5}} \mathbf{S}_{\mathbf{3}}$ & Above 28 \\
\hline $\mathbf{P}_{\mathbf{1}} \mathbf{S}_{\mathbf{4}}$ & Between 21 to 28 \\
\hline $\mathbf{P}_{\mathbf{2}} \mathbf{S}_{\mathbf{4}}$ & Between 21 to 28 \\
\hline $\mathbf{P}_{\mathbf{3}} \mathbf{S}_{\mathbf{4}}$ & Between 21 to 28 \\
\hline $\mathbf{P}_{\mathbf{4}} \mathbf{S}_{\mathbf{4}}$ & Between 21 to 28 \\
\hline $\mathbf{P}_{\mathbf{5}} \mathbf{S}_{\mathbf{4}}$ & Above 28 \\
\hline & \\
\hline
\end{tabular}


Fig.1 Effect of precooling and storage temperatures on PLW (\%) of mango fruits during storage

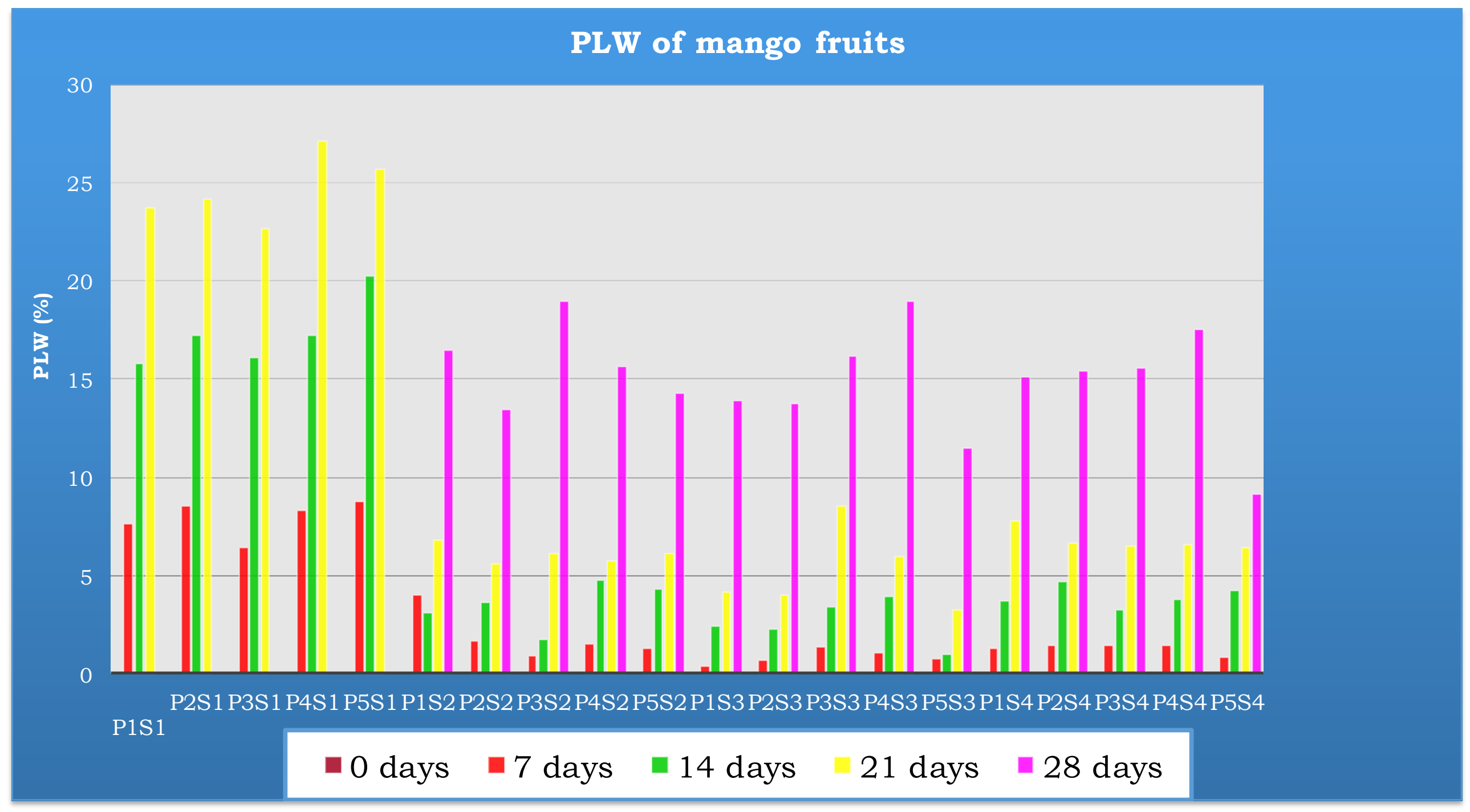

Precooling temperature: - 1) $\mathrm{P}_{1}-$ Control, 2) $\mathrm{P}_{2}-21 \pm 2^{\circ} \mathrm{C}$, 3) $\left.\mathrm{P}_{3}-18 \pm 2^{\circ} \mathrm{C}, 4\right) \mathrm{P}_{4}-15 \pm 2^{\circ} \mathrm{C}$, 5) $\mathrm{P}_{5}-12 \pm 2^{\circ} \mathrm{C}$ Storage temperature: - 1) $\mathrm{S}_{1}$ - Ambient temperature, 2) $\mathrm{S}_{2}-18 \pm 2^{\circ} \mathrm{C}$, 3) $\mathrm{S}_{3}-15 \pm 2^{\circ} \mathrm{C}$, 4) $\mathrm{S}_{4}-12 \pm 2^{\circ} \mathrm{C}$ 
Fig.2 Effect of precooling and storage temperatures on shriveling (\%) of mango fruits during storage

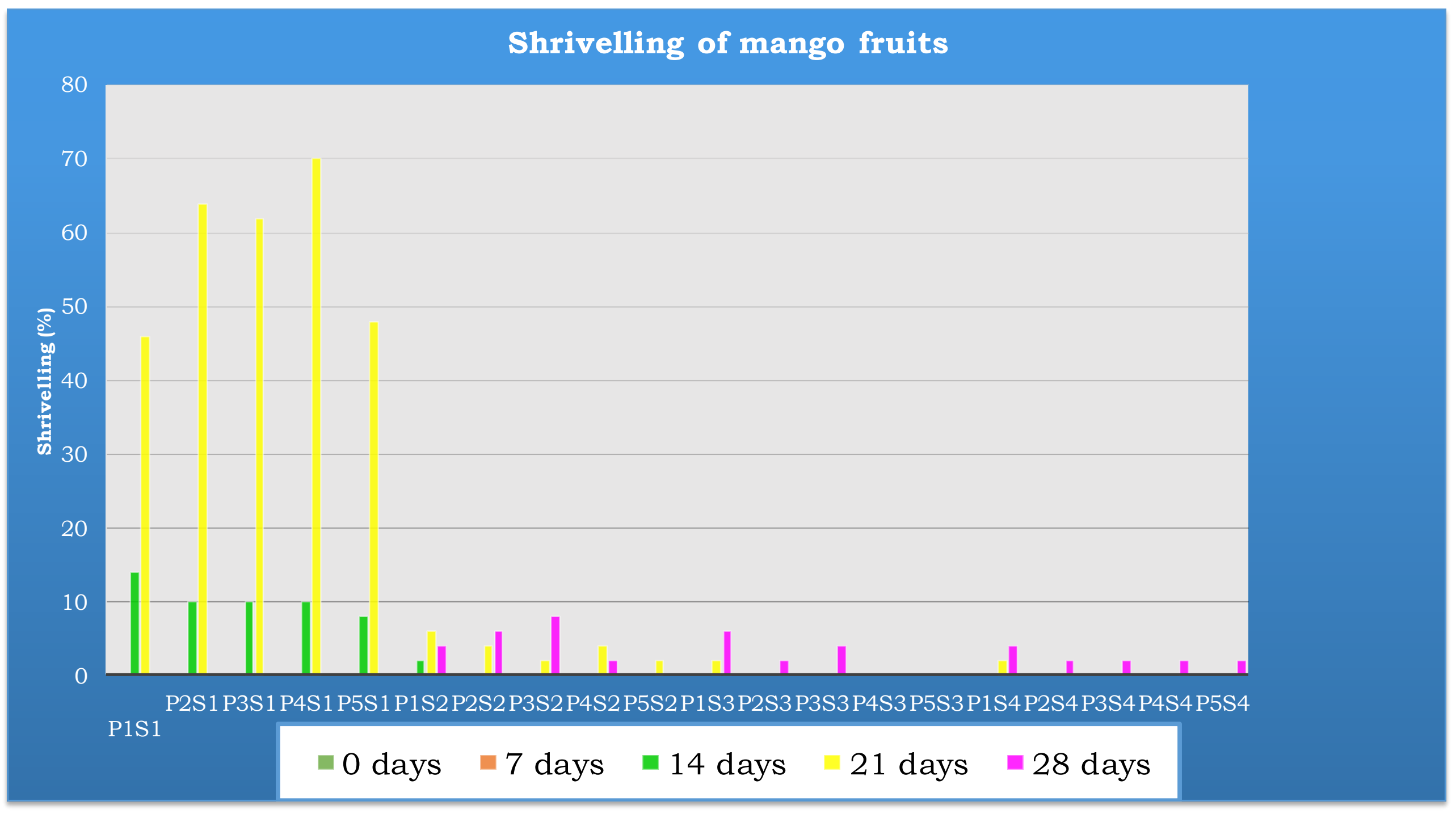

Precooling temperature: - 1) $\mathrm{P}_{1}$ - Control, 2) $\mathrm{P}_{2}-21 \pm 2^{\circ} \mathrm{C}$, 3) $\mathrm{P}_{3}-18 \pm 2^{\circ} \mathrm{C}$, 4) $\mathrm{P}_{4}-15 \pm 2^{\circ} \mathrm{C}$, 5) $\mathrm{P}_{5}-12 \pm 2^{\circ} \mathrm{C}$

Storage temperature: - 1) $\mathrm{S}_{1}$ - Ambient temperature, 2) $\left.\mathrm{S}_{2}-18 \pm 2^{\circ} \mathrm{C}, 3\right) \mathrm{S}_{3}-15 \pm 2^{\circ} \mathrm{C}$, 4) $\mathrm{S}_{4}-12 \pm 2^{\circ} \mathrm{C}$ 


\section{Int.J.Curr.Microbiol.App.Sci (2017) 6(11): 845-855}

Fig.3 Effect of precooling and storage temperatures on spoilage (\%) of mango fruits

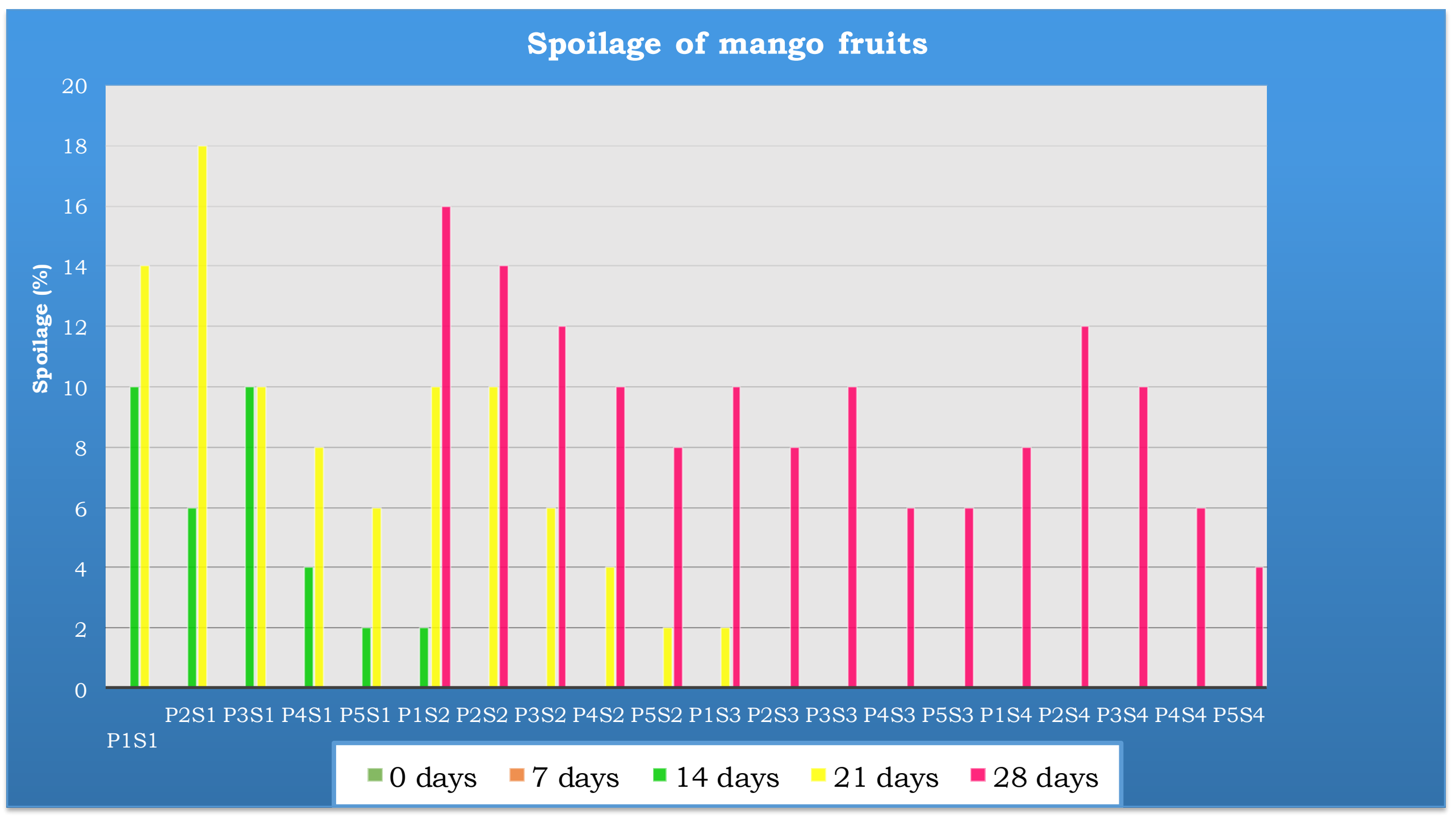

Precooling temperature: - 1) $\mathrm{P}_{1}-$ Control, 2) $\mathrm{P}_{2}-21 \pm 2^{\circ} \mathrm{C}$, 3) $\mathrm{P}_{3}-18 \pm 2^{\circ} \mathrm{C}$, 4) $\mathrm{P}_{4}-15 \pm 2^{\circ} \mathrm{C}$, 5) $\mathrm{P}_{5}-12 \pm 2^{\circ} \mathrm{C}$

Storage temperature: - 1) $\mathrm{S}_{1}$ - Ambient temperature, 2) $\left.\mathrm{S}_{2}-18 \pm 2{ }^{\circ} \mathrm{C}, 3\right) \mathrm{S}_{3}-15 \pm 2^{\circ} \mathrm{C}$, 4) $\mathrm{S}_{4}-12 \pm 2^{\circ} \mathrm{C}$ 
Findings of this study are supported by Padhye (1997) and Devani et al., (2011) in mango.

\section{Shriveling (\%)}

It is seen from Table 2 and Figure 2 that fruits started shriveling on $14^{\text {th }}$ and $21^{\text {st }}$ days under ambient and cold storage, respectively. Fruits stored at ambient temperature $\left(S_{1}\right)$ recorded 10.4 per cent shriveling and cold storage $S_{2}$ $(0.4 \%), \mathrm{S}_{3}$ and $\mathrm{S}_{4}$ fruits recorded 0.00 per cent shriveling on $14^{\text {th }}$ days of storage. At $21^{\text {st }}$ days of storage the fruits stored at $12 \pm 2^{\circ} \mathrm{C}$ $\left(\mathrm{S}_{4}\right)$ and $15 \pm 2^{\circ} \mathrm{C}\left(\mathrm{S}_{3}\right)$ temperatures showed significantly lowest $(0.40 \%)$ shriveling however, it was found on par with $\mathrm{S}_{2}$ (3.60 $\%$ ). The minimum shrivelling of mango fruits $(12.5 \%)$ was observed at precooling temperature $12 \pm 2{ }^{\circ} \mathrm{C}\left(\mathrm{P}_{5}\right)$ which was at par with $\mathrm{P}_{1}(14 \%)$ and $\mathrm{P}_{3}(16 \%)$.

Minimum increase in shriveling was noticed in $\mathrm{S}_{3}$ and $\mathrm{S}_{4}(2.40 \%)$. In interactions the minimum increase in shrivelling was observed in $\mathrm{P}_{5} \mathrm{~S}_{2}, \mathrm{P}_{4} \mathrm{~S}_{3}$ and $\mathrm{P}_{5} \mathrm{~S}_{3}(0.00 \%)$ on the $28^{\text {th }}$ days of storage. The fruits stored at cold storage remained firm which resulted in minimum shrivelling as compared with ambient temperature storage. Such reduction in shrivelling was due to low temperature and high humidity conditions under cold storage. Similar results were reported by Badar (1990), Padhye (1997) and Kshirsagar (2004) in mango, which supported the present findings.

\section{Spoilage $(\%)$}

It is presented in Table 3 and Figure 3 that fruits spoilage started on $14^{\text {th }}$ and $21^{\text {st }}$ day under ambient and cold storage, respectively. Percentage of spoilage was in increasing order throughout the storage period in both the storage conditions. The fruits stored at ambient temperature $\left(S_{1}\right)$ recorded 6.4 per cent spoilage, cold storage $S_{2}$ recorded 0.4 per cent while, $S_{3}$ and $S_{4}$ fruits recorded 0.00 per cent spoilage, irrespective of precooling. Maximum spoilage was found in $\mathrm{P}_{1}(3 \%)$ while minimum was found in $\mathrm{P}_{5}(0.5 \%)$, irrespective of storage temperatures during the $14^{\text {th }}$ days of storage. At $21^{\text {st }}$ days of storage, 0.00 per cent spoilage was recorded in $\mathrm{S}_{4}$ treatment $\left(12 \pm 2^{\circ} \mathrm{C}\right)$, which was at par with $\mathrm{S}_{3}(0.40 \%)$. The minimum increase in spoilage was observed in $\mathrm{P}_{5}(2 \%)$, which was at par with $\mathrm{P}_{3}(4 \%)$, and $\mathrm{P}_{4}(3 \%)$. Minimum increase in spoilage was noticed in $\mathrm{S}_{3}$ and $\mathrm{S}_{4}$ $(8 \%)$ and in interactions, the minimum increase in spoilage was observed in $\mathrm{P}_{5} \mathrm{~S}_{4}$ $(4.00 \%)$ on the $28^{\text {th }}$ days of storage. It was noticed from the data that the maximum spoilage was recorded in ambient storage as compared to cold storage. It may be due to high temperature congenial for growth of microorganism was available at ambient storage. Present findings are in agreement with the results reported by Khanbarad et al., (2013) and Makwana et al., (2014) in mango.

\section{Shelf Life (Days)}

With respect to shelf life, cold storage fruits recorded maximum shelf life as compared to ambient temperature stored fruits that is recorded in Table 4. Among the different interactions tried, maximum shelf life (28 days) was observed in $\mathrm{P}_{5} \mathrm{~S}_{3} \quad\left(12 \pm 2{ }^{0} \mathrm{C}\right.$ precooling and $15 \pm 2{ }^{0} \mathrm{C}$ storage temperature) and $\mathrm{P}_{5} \mathrm{~S}_{4}\left(12 \pm 2{ }^{0} \mathrm{C}\right.$ precooling and storage temperature) as these fruits recorded less PLW and spoilage.

This might be due to the reduction in field heat in shortest possible time, lower moisture loss, restricted metabolic and respiratory activities and inhibition in water loss and reduction in ethylene production in fruits (Hardenberg et al., 1990). The similar finding reported by Padhye (1997), Devani et al., (2011) and Khanbarad et al., (2013). 


\section{References}

Anonymous (2015 a). Area, production and productivity of mango in India. Indian Horticulture Database.

Anonymous (2015 b). Mango output up 2.2\% in 2014-15. The Hindu business line.

Badar R. S. (1990). Studies on maturity indices, grading and storage of mango (Mangifera indica L.) fruits Cv. Ratna and Kesar. M.Sc. (Agri.) Thesis submitted to Konkan Krishi Vidyapeeth, Dapoli, Ratnagiri (M.S.).

Devani R. B.; K. M. Karetha and Virendra Singh (2011). Effect of pre-cooling and storage methods for extending the shelf life and quality of mango cv. Kesar fruits. International J. Processing and Post-Harvest Technology. 2(2): 117120.

Hardenburg R. E.; A. F. Watada and C. Y. Wang (1990). The commercial storage of fruits vegetable and florist and nursery stocks, U. S. Dept. Agr. Handbook No. 66, pp. 3.

Khanbarad S. C., N. Patil, R. F. Sutar and D. C. Joshi (2013) Studies on pre-cooling of mango for extension of shelf-life. $J$. of Agricultural Engineering., 50(4).

Krishnamurthy S. and D. V. S. Rao, (2001). Status of post-harvest management of fruits. Indian J. Hort., 58(1-2): 152.

Kshirsagar P. B. (2004). Studies on fruiting and some aspects of post- harvest handling of some promising varieties of mango (Mangifera indica L.). A M. Sc. (Agri.) thesis submitted to Dr. Balasaheb Sawant Konkan Krishi Vidyapeeth, Dapoli, Ratnagiri, Maharashtra.

Makwana S.A.; N.D. Polara and R.R. Viradia (2014). Effect of pre-cooling on postharvest life of mango (Mangifera indica L.) cv. Kesar. Food Science Technology. 2(1): 6-13.

Mukherjee S. K. (1951). The origin of mango. Indian J. Genet. 2: 49.

Padhye B. P. (1997). Studies on some aspect of post-harvest handling of mango (Mangifera indica L.) Cv. Alphonso. M.Sc. (Agri.) thesis (unpublished) submitted to Dr. Balasaheb Sawant Konkan Krishi Vidyapeeth, Dapoli, Dist. Ratnagiri (Maharashtra).

\section{How to cite this article:}

Kanade, N.M., C.D. Pawar, V.S. Ghule, R.C. Gajbhiye and Salvi, B.R. 2017. Effect of Different Precooling and Storage Temperatures on Shelf Life of Mango cv. Alphonso. Int.J.Curr.Microbiol.App.Sci. 6(11): 845-855. doi: https://doi.org/10.20546/ijcmas.2017.611.099 